\title{
BAURAN PEMASARAN KEPUASAN DAN LOYALITAS PELANGGAN BENIH KELAPA SAWIT PT SOCFIN INDONESIA
}

\author{
Sri Ariani Safitri, Suharno dan Anna Fariyanti \\ Fakultas Ekonomi dan Manajemen, Institut Pertanian Bogor \\ sri.ariani.sp@gmail.com
}

\begin{abstract}
Along with the increasing demand of palm oil seed trigger an increased number of seed producers of palm oil in Indonesia. Under conditions of tight competition, PT Socfin Indonesia (Socfindo) as one of the producers of palm oil seed needs to evaluate the performance of the marketing mix (product, price, place and promotion) through customer satisfaction and loyalty. This study aimed to analyze the influence of marketing mix towards customer satisfaction and loyalty as well as to analyze the level of satisfaction and loyalty customer palm oil seed of PT Socfindo. The collection of data through the 30 respondent companies. Data analysis methods used Structural Equation Model Partial Least Square (SEM PLS). Analysis results showed that the the product variables have a significant influence on customer satisfaction and loyalty, while the variables of price, place and promotion does not have a significant influence in shaping customer satisfaction and loyalty. In addition, the calculation results Customer Satisfaction Index (CSI), customer satisfaction index palm oil seed PT Socfindo which can be categorized as very satisfied and calculating results Customer Loyalty Index (CLI), an index of customer loyalty palm oil seed PT Socfindo which can be categorized loyal.
\end{abstract}

Keywords: Palm Oil Seed, Marketing Mix, Customer Satisfaction, Customer Loyalty, Structural Equation Model Partial Least Square (SEM PLS)

\begin{abstract}
Abstrak: Seiring dengan meningkatnya permintaan benih kelapa sawit memicu meningkatnya jumlah produsen benih kelapa sawit di Indonesia. Dalam kondisi persaingan yang semakin ketat, PT Socfin Indonesia (Socfindo) sebagai salah satu produsen benih kelapa sawit perlu melakukan evaluasi kinerja bauran pemasaran (produk, harga, tempat dan promosi) melalui kepuasan dan loyalitas pelanggan. Penelitian ini bertujuan untuk menganalisis pengaruh kinerja bauran pemasaran terhadap kepuasan dan loyalitas pelanggan serta menganalisis tingkat kepuasan dan loyalitas pelanggan benih kelapa sawit PT Socfindo. Pengumpulan data melalui 30 responden perusahaan. Metode analisis data yang digunakan Structural Equation Model Partial Least Square (SEM PLS). Hasil analisis menunjukkan bahwa variabel produk memiliki pengaruh yang signifikan terhadap kepuasan dan loyalitas pelanggan, sedangkan variabel harga, tempat dan promosi tidak memiliki pengaruh yang signifikan dalam membentuk kepuasan dan loyalitas pelanggan. Selain itu, hasil perhitungan Customer Satisfaction Index (CSI), indeks kepuasan pelanggan benih kelapa sawit PT Socfindo dapat dikategorikan sangat puas dan hasil perhitungan Customer Loyalty Index (CLI), indeks loyalitas pelanggan benih kelapa sawit PT Socfindo dapat dikategorikan loyal.
\end{abstract}

Kata Kunci: Benih Kelapa Sawit, Bauran Pemasaran, Kepuasan Pelanggan, Loyalitas Pelanggan, Structural Equation Model Partial Least Square (SEM PLS) 


\section{PENDAHULUAN}

Kelapa sawit merupakan salah satu hasil perkebunan sebagai minyak edible yang paling banyak diperdagangkan. Oleh sebab itu kelapa sawit berperan penting dalam kegiatan perekonomian di Indonesia baik di pasar domestik maupun pasar internasional. Sejak tahun 2008 minyak kelapa sawit mampu menggeser dominasi minyak kedelai dan sekaligus menempatkan minyak kelapa sawit sebagai sumber penting minyak nabati dunia (GAPKI, 2014).

Seiring dengan peningkatan jumlah penduduk dunia, maka permintaan akan kebutuhan CPO dan produk-produk turunan dari kelapa sawit juga semakin meningkat. Hal ini juga berpengaruh positif terhadap perkembangan industri kelapa sawit. Berdasarkan Gambar 1, terjadi peningkatan rata-rata luas areal kelapa sawit dari tahun 2009 sampai pada tahun 2015* mencapai 9.7 juta ha per tahun dengan persentase kenaikan rata-rata 5.8 persen per tahun. Selain itu, peningkatan produksi CPO juga meningkat dengan rata-rata 25.7 juta ton per tahun dan persentase kenaikan produksi rata-rata 6.2 persen setiap tahunnya (BPS, 2014). Adanya keterkaitan ke belakang (backward linkage) dari subsistem hilir ke subsistem hulu sehingga peningkatan luas areal berdampak langsung terhadap meningkatnya permintaan benih kelapa sawit (Liwang et al., 2011).

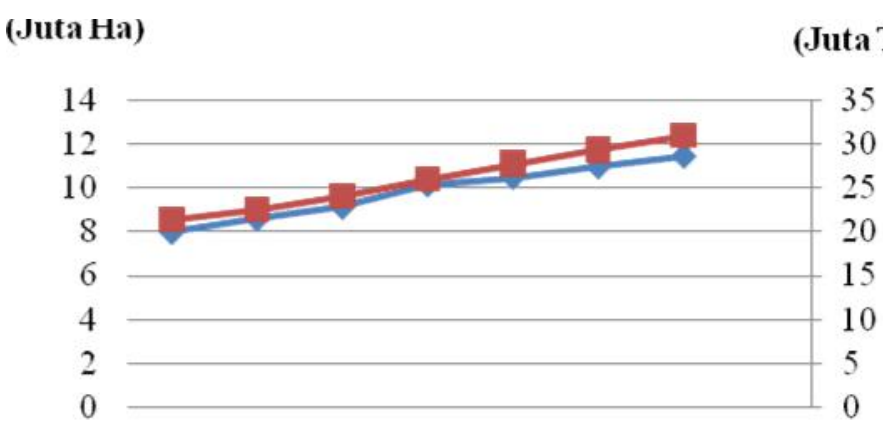

2009201020112012201320142015

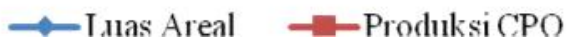

Gambar 1 Perkembangan luas areal dan produksi perkebunan kelapa sawit Sumber: (BPS, 2014)

Selain untuk kebutuhan perluasan areal baru, benih kelapa sawit juga digunakan untuk penanaman ulang (replanting) kebun kelapa sawit yang telah ada. Dengan asumsi umur produktif kelapa sawit 25 tahun, maka tanaman kelapa sawit akan mengalami penanaman ulang (replanting) sebesar 4 persen dari luas areal atau setara dengan 400 ribu hektar setiap tahun. Pentingnya penyediaan benih kelapa sawit unggul, karena cetak biru sifatsifat ekonomis tanaman kelapa sawit seperti produktivitas dan rendemen minyak dimulai pada industri perbenihan (GAPKI, 2014).

Terjadinya peningkatan permintaan benih kelapa sawit menyebabkan industri benih kelapa sawit di Indonesia mengalami persaingan yang semakin ketat. Pada awalnya hanya terdapat tiga produsen benih kelapa sawit, yakni Pusat penelitian kelapa sawit (PPKS), PT London sumatera (Lonsum) dan PT Socfin Indonesia (Socfindo). Berdasarkan Gambar 1, pada tahun 2014 produsen benih kelapa sawit bertambah menjadi sepuluh perusahaan dengan pasar terbesar dimiliki oleh PT Socfindo yakni 32 persen disusul oleh PPKS 23 
persen dan PT Dami Sejahtera 14 persen. Hingga pada tahun 2016 produsen benih kelapa sawit semakin bertambah menjadi empat belas perusahaan, perusahaan baru tersebut yakni PT. ASD-Bakrie, PT Gunung Sejahtera Ibu Pertiwi (GSIP/Astra Group), PT Dura Inti Lestari, PT Aneka Sawit Lestari, dan PT Perkebunan Nusantara IV (DITJETBUN, 2016). Pada pasar yang sangat kompetitif saat ini, perusahaan lebih tertantang untuk meningkatkan atau bahkan mempertahankan pangsa pasar (Li dan Green, 2012). Dinamika pangsa pasar benih kelapa sawit mengalami perubahan yang diakibatkan oleh bertambahnya produsen benih domestik baru (new entry). Hal ini tentunya akan mengurangi pangsa pasar dari tiga produsen benih domestik yang ada sebelumnya. Perubahan struktur pasar benih kelapa sawit menjadi pasar oligopoli pada tingkat konsentrasi tinggi akan mempengaruhi perilaku konsumen dan strategi perusahaan. Selain itu, kinerja perusahaan industri sangat dipengaruhi oleh struktur pasar (Liwang et al., 2012).

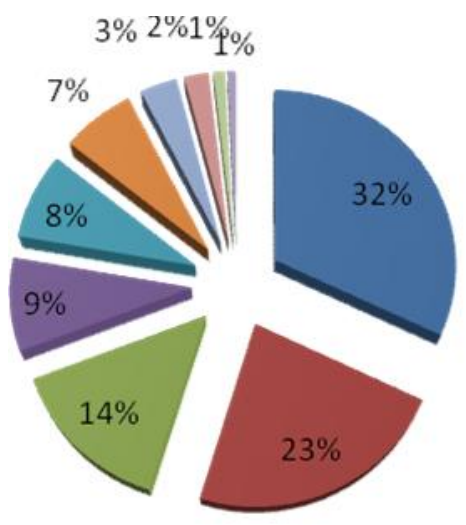

$=$ PT. Socfindo
$=$ PPKS
$=$ PT. Dami Mas Sejahtera
$=$ PT. TYE (asian agri)
$=$ PT. BSM (sampoerna)
$=$ PT. Lonsum
$=$ PT. Sarana Inti Pratama
$=$ PT. Bakti Tani Nusantara
$=$ PT. Tania Selatan
$=$ PT. Sasaran Fhsan Mekarsari

Gambar 2 Pangsa pasar produsen benih kelapa sawit di Indonesia tahun 2014 Sumber: (GAPKI, 2014)

PT Socfin Indonesia (Socfindo) adalah salah satu perusahaan produsen benih unggul kelapa sawit yang berada di Medan Provinsi Sumatera Utara. Pelanggan PT Socfindo didominasi oleh pelanggan bisnis yang meliputi perusahaan perkebunan baik swasta dan Badan Usaha Milik Negara (BUMN) yang tersebar di beberapa provinsi di Indonesia. Saat ini PT Socfindo telah menghasilkan tiga jenis varietas benih kelapa sawit unggul yakni DxP Lame, Yangambi dan DxP MT Gano. Setiap varietas benih kelapa sawit PT Socfindo memiliki keunggulan masing-masing yang menunjukkan ciri khas dari varietas tersebut.

Adanya peningkatan jumlah produsen benih kelapa sawit berpengaruh terhadap PT Socfindo sebagai perusahaan lama pada pasar benih kelapa sawit di Indonesia. Selain tantangan penurunan pangsa pasar, pada tahun 2011 sampai tahun 2014 juga terjadi penurunan persentase jumlah pesanan dari pelanggan benih kelapa sawit PT Socfindo dari 67.9 persen menjadi 60.3 persen. Hal ini mengindikasi adanya pembagian persentase belanja benih kelapa sawit pelanggan PT Socfindo ke produsen benih kelapa sawit lain.

Sebagai perusahaan yang bergerak pada bidang industri benih kelapa sawit di Indonesia. PT Socfindo perlu membuat langkah strategis dalam menyikapi perubahan pasar tersebut. Pada kondisi persaingan yang ketat, mencari pelanggan baru membutuhkan biaya dan waktu yang lebih besar dibandingkan mempertahankan pelanggan yang sudah ada (Wills, 2009). Salah satu hambatan untuk pindah (switching barrier) yang dapat 
dilakukan untuk tetap mempertahankan pelanggan yakni dengan cara membentuk loyalitas pada pelanggan. Loyalitas pelanggan merupakan sumber penting dari keunggulan kompetitif dan memiliki pengaruh yang kuat terhadap kinerja perusahaan (Almuala dan Alqurneh, 2012). Dengan melakukan evaluasi kinerja bauran pemasaran terhadap kepuasan dan loyalitas pelanggan melalui informasi baru dari pelanggan diharapkan dapat meningkatkan kepuasan dan loyalitas serta dapat merancang strategi baru dalam menghadapi persaingan pasar yang semakin kompetitif.

\section{KAJIAN TEORI}

Bauran Pemasaran. Bauran pemasaran merupakan kombinasi dari berbagai elemen yang digunakan sebagai alat strategi pemasaran. Dalam merancang bauran pemasaran, perusahaan fokus pada dua proses strategis. Proses pertama adalah memilih pasar mana yang ingin menjadi target pasar dan yang kedua adalah prosedur pengembangan $4 \mathrm{P}$ yakni menggabungkan semua aspek bauran pemasaran seperti harga, tempat, produk dan promosi untuk memuaskan pelanggan (Kanagal, 2009).

Pada tahun 1960-an Jerome McCarthy memperkenalkan konsep marketing mix yang dikenal dengan teori 4P. Pada awalnya konsep ini secara ringkas menjelaskan praktik generik dari manajemen produk, yakni membuat sebuah produk (product), menentukan harganya (price), melakukan promosi (promotion), dan merancang tempat distribusi (place). 3P terakhir terutama digunakan di sektor jasa daripada barang yang memberikan penelitian bukti kuat. Namun adanya perkembangan tuntutan pasar dari dampak perkembangan perilaku konsumen, maka ada perspektif baru yang modern dalam memandang bauran pemasaran perusahaan yakni menjadi (7P). Tambahan (3P) yakni people, physical evidence dan process. Ketiga elemen tersebut terkait dengan sifat jasa atau layanan dari produk yang diproduksi (Levens, 2010). Namun pada penelitian ini menggunakan bauran pemasaran $4 \mathrm{P}$ karena sektor produk lebih memberikan bukti penelitian yang kuat daripada sektor jasa.

Kinerja dari bauran pemasaran merupakan cerminan atas kinerja perusahaan. Perusahaan yang berhasil pada dasarnya mampu memainkan kombinasi "P" secara efisien dan efektif yang didukung oleh keputusan yang inovatif (Kotler dan Keller, 2009). Berikut penjelasan mengenai elemen bauran pemasaran $4 \mathrm{P}$ yang berupa produk, harga, distribusi dan promosi.

1. Produk (product). Kotler dan Keller, (2009) menyatakan bahwa barang atau jasa yang diluncurkan di pasar untuk dikonsumsi atau digunakan oleh pelanggan disebut produk. Produk adalah aspek utama dari bauran pemasaran (Nuseir dan Madanat, 2015). Produk dibagi menjadi tiga bagian yakni inti, aktual, serta tambahan. Inti merupakan nilai serta manfaat yang dimiliki suatu produk. Aktual merupakan wujud konkrit dari produk seperti mutu, merek, kemasan, serta desain. Untuk selanjutnya, tambahan merupakan layanan purna jual produk seperti garansi, pemasangan, pemeliharaan, retur dan lain sebagainya (Kotler dan Keller, 2009).

2. Harga (price). Harga adalah sejumlah uang atau biaya yang dikenakan untuk produk atau layanan, atau total nilai yang yang ditukarkan konsumen atas manfaat memiliki atau menggunakan produk atau jasa. Harga adalah salah satu alat bauran pemasaran yang digunakan perusahaan untuk mencapai tujuan pemasarannya. Keputusan harga harus dihubungkan dengan keputusan rancangan produk, distribusi, dan promosi untuk membuat program pemasaran yang efektif sehingga mencapai tujuan pemasaran. Keputusan yang 
dibuat untuk variabel-variabel bauran pemasaran lainnya mempengaruhi keputusan penetapan harga (Kotler dan Keller, 2009).

Harga merupakan hal yang sangat sensitif pada konsumen. Jika suatu perusahaan sebagai market leader menurunkan harga, maka para pesaingnya harus menurunkan harga pula. Harga merupakan satu-satunya faktor yang strategi bauran pemasaran yang menghasilkan pendapatan bagi perusahaan, sedangkan bauran pemasaran yang lainnya terkait dengan biaya. Komponen dari elemen bauran pemasaran harga yakni daftar harga, diskon, potongan harga khusus, periode pembayaran dan syarat kredit (Kotler dan Keller, 2009).

3. Distribusi (place). Distribusi yakni berbagai kegiatan perusahaan untuk membuat produk dan penyampaian produk atau jasa dari produsen ke konsumen, sehingga penggunaannya sesuai dengan yang diperlukan (jenis, jumlah, harga, tempat, dan waktu saat dibutuhkan). Berdasarkan (Nuseir dan Madanat, (2015), konsep distribusi merupakan faktor utama untuk memenuhi permintaan produk ke pasar yang ditargetkan. Kotler dan Keller, (2009) menyatakan bahwa elemen bauran pemasaran tempat terdiri dari beberapa komponen yakni saluran pemasaran, cakupan pasar, pengelompokan lokasi, persediaan dan transportasi.

4. Promosi (promotion). Promosi merupakan suatu bentuk komunikasi pemasaran dan sebagai salah satu faktor penentu keberhasilan pemasaran. Promosi sangat penting karena menyediakan informasi, saran, dan membujuk target pasar (Almuala dan Alqurneh, 2012). Produk yang berkualitas, bila konsumen belum pernah mendengarnya tidak yakin akan kualitas dari produk tersebut, maka konsumen tidak akan pernah membelinya.

Kotler dan Keller, (2009) membagi komponen promosi menjadi beberapa bagian, yakni iklan, promosi penjualan, tenaga penjualan dan pemasaran langsung. Promosi bertujuan untuk membangun kesadaran konsumen akan suatu produk maupun jasa dan membangun pemahaman akan suatu produk sebagai upaya untuk mengingatkan konsumen akan suatu produk maupun jasa, menciptakan langkah awal bagi perusahaan, dan sebagai alat untuk melegitimasi keberadaan perusahaan dan produknya, serta digunakan sebagai alat untuk meyakinkan kembali produknya ke konsumen.

Kepuasan Pelanggan. Kepuasan pelanggan merupakan faktor kunci dalam pembentukan keinginan pelanggan untuk pembelian di masa depan (Mosahab et al., 2010). Kotler dan Keller, (2009) menyatakan bahwa kepuasan pelanggan merupakan suatu tingkatan dimana perkiraan kinerja produk sesuai dengan harapan pembeli. Kepuasan pelanggan berkaitan erat dengan kualitas. Mutu atau kualitas produk mempunyai pengaruh langsung terhadap kinerja produk dengan demikian berpengaruh juga terhadap kepuasan pelanggan.

Kepuasan pelanggan dapat memberikan beberapa manfaat, diantaranya hubungan antara perusahaan dan pelanggannya menjadi harmonis. Kepuasan pelanggan juga bergantung kepada kualitas dari produk dan jasa yang dihasilkan dari suatu perusahaan. Terdapat keterkaitan yang erat antara kualitas produk dan jasa, kepuasan pelanggan dan profitabilitas. Semakin tinggi tingkat kualitas suatu produk, maka semakin tinggi tingkat kepuasan konsumen yang dihasilkan, didukung dengan harga yang lebih tinggi dan biaya yang lebih rendah. Hal ini tentunya akan meningkatkan profitabilitas perusahaan (Kotler dan Keller, 2009).

Dutka, (2008) menyatakan, terdapat tiga dimensi dalam mengukur kepuasan pelanggan secara universal yaitu 1). Attributes related to product yaitu dimensi kepuasan yang berkaitan dengan atribut dari produk seperti penetapan nilai yang didapatkan dengan harga, kemampuan produk menentukan kepuasan, benefit dari produk tersebut. 2). 
Attributes related to service yaitu dimensi kepuasan yang berkaitan dengan atribut dari pelayanan misalnya dengan garansi yang dijanjikan, proses pemenuhan pelayanan atau pengiriman, dan proses penyelesaian masalah yang diberikan. 3). Attributes related to purchase yaitu dimensi kepuasan yang berkaitan dengan atribut dari keputusan untuk membeli atau tidaknya dari produsen seperti kemudahan mendapat informasi, kesopanan karyawan dan juga pengaruh reputasi perusahaan.

Loyalitas Pelanggan. Pentingnya loyalitas pelanggan dalam pemasaran adalah hal mutlak. Loyalitas pelanggan merupakan komitmen yang dipegang pelanggan untuk membeli kembali, meski situasi persaingan yang semakin meningkat berpotensi menyebabkan pelanggan beralih (Kotler dan Keller, 2009). Dengan kata lain, loyalitas pelanggan adalah pelanggan yang merasa puas terhadap produk atau merek yang dipakai, dan akan membeli produk ulang tersebut. Loyalitas pelanggan memainkan peran penting dalam kesuksesan perusahaan. Pelanggan yang setia memberikan perusahaan sumber pendapatan yang konsisten dari meningkatnya pembelian ulang dan pengurangan biaya promosi sehingga meningkatkan profitabilitas (Li dan Green, 2012).

Loyalitas pelanggan merupakan tujuan penting bagi perencanaan pemasaran strategis dan merupakan dasar penting untuk mengembangkan keunggulan kompetitif yang berkelanjutan Pelanggan yang loyal akan menjadi aset yang sangat bernilai bagi perusahaan. Selain itu pelanggan yang loyal akan mengurangi biaya untuk memperoleh konsumen baru dan memberikan umpan balik positif bagi perusahaan (Suwarni, 2011). Oleh karena itu, loyalitas konsumen berdasarkan kepuasan merupakan salah satu aset terbesar yang mungkin didapat oleh perusahaan.

Berdasarkan Tjiptono, (2008) terdapat enam indikator yang bisa digunakan untuk mengukur loyalitas pelanggan, yaitu 1) pembelian berulang, 2) kebiasaan mengkonsumsi merek tersebut, 3) selalu menyukai merek tersebut, 4) tetap pada merek tersebut, 5) memiliki keyakinan bahwa merek tersebut yang terbaik, dan 6) merekomendasikan merek tersebut pada pihak lain. Selain itu Raab et al., (2008) mengemukakan bahwa alasan pelanggan melakukan pembelian ulang berbeda-beda tergantung motif atau tujuan tertentu, yaitu:

1. Situasional. Pelanggan melakukan pembelian ulang salah satunya karena motif situasional.Hal ini berhubungan dengan segala faktor eksternal. Misalnya faktor jarak atau pembelian berulang karena motifsituasional bisa terjadi karena pelanggan telah terbiasa melakukan pembelian tersebut. Pelanggan yang sudah terbiasa akan secara otomatis membeli produk/jasa dari perusahaan yang sama tanpa ada rasa loyal kepada perusahaan tersebut.

2. Kontraktual. Adanya kontrak atau kondisi tertentu dimana pada waktu tertentu pelanggan mendapatkan keuntungan dari pembelian berulang kepada suatu perusahaan. Namun, ketika keuntungan tersebut telah berakhir/habis maka pelanggan akan mengakhiri pembelian berulangnya.

3. Ekonomi. Pelanggan melakukan pembelian berulang terhadap perusahaan karenaproduk/jasa yang ditawarkan perusahaan memberikan harga yang sesuai atau karena pesaing belum bisa memberikan harga yang lebih rendah kepada produk/jasa sejenis. Pelanggan dengan motif ekonomi seperti ini bukanlah pelanggan yang loyal. Ketika pendapatan pelanggan tersebut meningkat dan mereka mampu membeli produk/jasa yang memiliki kualitas lebih baik dari perusahaan pesaing, maka pelanggan akan meninggalkan perusahaan tersebut. 
4. Teknikal/Fungsional. Pelanggan melakukan pembelian berulang berdasarkan manfaat yang dirasakan atas produk/jasa tersebut. Pelanggan telah komitmen dalam menetapkan standarnya terhadap produk/jasa yang akan digunakannya padasaat awal pembelian. Pergantian terhadap merek akan menurunkan standarnya dan menghadapi banyak persoalan baru sehingga pelanggan memutuskan untuk melakukan pembelian ulang terhadap perusahaan yang sama.

5. Psikologis. Pada motif ini pelanggan tidak mendasari pembelian ulangnya berdasarkan keuntungan secara materi, melainkan pelanggan merasakan keterikatan dengan perusahaan. Pelanggan yang melakukan pembelian ulang berdasarkanmotif ini, sangat berpotensi untuk menjadi pelanggan yang loyal. Pelanggan ini akan kebal dalam menghadapi tarikan dari perusahaan pesaing karena pelanggan ini mendasari pembeliannya berdasarkan keterikatan.

Pengaruh Bauran Pemasaran Terhadap Kepuasan dan Loyalitas. Hubungan mengenai bauran pemasaran, kepuasan pelanggan dan loyalitas pelanggan memiliki hubungan yang saling berkaitan. Hasil penelitian menunjukkan bahwa bauran pemasaran berpengaruh positif dan signifikan terhadap kepuasan pelanggan benih (Koes, 2013; Liwang et al., 2011).

Selain itu, Chinomona dan Dubihlela, (2014) menyatakan bahwa tingkat kepuasan pelanggan terhadap komponen bauran pemasaran memberikan kontribusi besar terhadap keinginan rekomendasi oleh pelanggan kepada pihak lain. Terdapat hubungan antara kepuasan pelanggan dalam mewujudkan loyalitas pelanggan, maka hal ini akan berimbas signifikan terhadap peningkatan penjualan (Liwang et al., 2011). Oleh sebab itu, kemampuan perusahaan dalam menciptakan kebutuhan dan keinginan pelanggan sangat dibutuhkan, karena hal ini yang selanjutnya akan mewujudkan loyalitas dari pelanggan. Dengan adanya pelanggan yang loyal, tujuan perusahaan atau organisasi jangka panjang akan lebih mudah tercapai.

Bauran pemasaran tidak berpengaruh langsung terhadap terhadap loyalitas pelanggan. Kepuasan pelanggan merupakan variabel yang memediasi hubungan antara bauran pemasaran dan loyalitas (Almuala dan Alqurneh, 2012). Dengan kata lain dimensi bauran pemasaran berpengaruh langsung ataupun tidak langsung terhadap loyalitas konsumen melalui kepuasan pelanggan. Ini artinya apabila perusahaan meningkatkan kinerja bauran pemasaran dengan harapan adanya peningkatan terhadap kepuasan pelanggan, maka hal tersebut dapat menciptakan loyalitas pelanggan.

\section{METODE}

Sumber data pada penelitian ini berasal dari data primer dan data sekunder. Data primer diperoleh melalui wawancara dengan menggunakan instrumen berupa kuesioner. Data sekunder merupakan data pendukung yang diperoleh dari instansi terkait yaitu Badan Pusat Statistik, Direktorat Jenderal Perkebunan Kementerian Pertanian, Gabungan Pengusaha Kelapa Sawit Indonesia (GAPKI) dan PT Socfindo. Selain itu, metode pengambilan sampel menggunakan metode Non Probability Sampling, yaitu secara purposive. Peneliti memilih dan menentukan sendiri responden yang akan dijadikan responden dengan pertimbangan pelanggan yang akan dijadikan responden merupakan pelanggan institusi/perusahaan. 
Pengaruh bauran pemasaran terhadap kepuasan dan loyalitas pelanggan dijelaskan dengan analisis Structural Equation Model Partial Least Square (SEM PLS). Analisis ini merupakan metode alternatif yang dapat digunakan untuk mengatasi permasalahan hubungan diantara variabel namun ukuran sampel datanya relatif kecil atau minimal direkomendasikan berkisar dari 30 sampai 100 sampel (Kurniawan, 2011; Latan dan Ghozali, 2015). Sehingga jumlah sampel yang digunakan dalam penelitian ini adalah 30 responden perusahaan. Melalui metode analisis Structural Equation Model Partial Least Square (SEM PLS) dapat diperoleh bobot, hubungan, serta pengaruh variabel indikator (variabel manifest) maupun variabel laten terhadap loyalitas pelanggan. Variabel indikator diukur dengan menggunakan skala likert empat skala dengan rentang sangat setuju hingga sangat tidak setuju.

Variabel-variabel yang digunakan dalam penelitian ini terdiri dari variabel laten eksogen bauran pemasaran, variabel laten endogen kepuasan dan loyalitas serta variabel manifes sebagai indikator dari variabel laten. Total variabel indikator pada penelitian ini adalah sembilan belas variabel indikator. Variabel indikator berasal dari tinjauan teori, hasil penelitian sebelumnya mengenai benih kelapa sawit dan hasil pengamatan pada prasurvey. Adapun variabel laten dan variabel indikator yang akan digunakan dalam penelitian ini dapat dilihat pada Tabel 1.

Tabel 1. Variabel laten dan variabel manifest

\begin{tabular}{ll}
\hline Variabel Laten & Variabel Manifest \\
& Daya kecambah benih (X11) \\
& Homogenitas benih (X12) \\
Produk & Ketahanan tanaman kelapa sawit terhadap hama dan penyakit (X13) \\
& Rerata produksi TBS (X14) \\
& Rerata ekstraksi CPO (X15) \\
& Kualitas kemasan benih (X16) \\
& Layanan purna Jual (X17) \\
Harga & Harga benih sesuai mutu (X21) \\
& Harga benih sesuai diinginkan (X22) \\
Tempat & Kemudahan akses (X31) \\
& Ketepatan waktu (X32) \\
Promosi & Kerjasama pihak lain (X41) \\
& Iklan (X42) \\
& Bonus pembelian (X43) \\
& Penjualan perorangan (X44) \\
& Berdasarkan pengalaman Pelanggan puas terhadap kualitas benih \\
Kepuasan Pelanggan & kelapa sawit (Y11) \\
Loyalitas Pelanggan membeli (Y21) & Tetap membeli meski ada produsen lain (Y22) \\
& Rekomendasi kepada pihak lain (Y23) \\
\hline
\end{tabular}

Selanjutnya untuk menentukan status tingkat kepuasan pelanggan dan loyalitas pelanggan benih kelapa sawit melalui perhitungan Customer Satisfaction Index (CSI) dan Customer Loyalty Index (CLI). Customer Satisfaction Index (CSI) diperoleh melalui total penjumlahan dari seluruh hasil perkalian antara bobot dengan persentase jumlah jawaban puas yakni setuju (skor 3) dan sangat setuju (skor 4). Bobot pada masing-masing indikator dapat diperoleh dari hasil analisis pada Structural Equation Model Partial Least Square 
(SEM PLS), yakni berupa pembagian antara besar pengaruh per indikator dengan total besar pengaruh, dimana besar pengaruh. adalah:

Rumus perhitungan Customer Satisfaction Index (CSI) (Yamin dan Kurniawan, 2009)

$$
\sum_{i=1}^{n} \text { (Bobot x Persentase Jumlah Jawaban Puas) }
$$

Tingkat kepuasan pelanggandapat dilihat dari kriteria nilai indeks kepuasan pelanggan. Adapun kriteria nilai CSI adalah sebagai berikut:

Tabel 2. Kriteria nilai customer satisfaction index

\begin{tabular}{cc}
\hline Angka Indeks & Tingkat Kepuasan \\
\hline $0.00 \leq \mathrm{x} \leq 24.99$ & Sangat Tidak Puas \\
$25.00<\mathrm{x} \leq 49.99$ & Tidak Puas \\
$50.00<\mathrm{x} \leq 74.99$ & Puas \\
$75.00<\mathrm{x} \leq 100.00$ & Sangat Puas \\
\hline
\end{tabular}

Sumber: (Rangkuti, 2005)

Selanjutnya rumus perhitungan Customer Loyalty Index (CLI) (Yamin dan Kurniawan, 2009) adalah :

$$
\frac{\left[\sum_{i=1}^{n}(\text { Bobot X Persentase Jumlah Jawaban Loyal })+\text { CSI }\right]}{2}
$$

Tingkat loyalitas pelanggan dapat dilihat dari kriteria nilai index loyalitas pelanggan. Adapun kriteria nilai Customer Loyalty Index (CLI) adalah sebagai berikut :

Tabel 3 Kriteria nilai customer loyalty index

\begin{tabular}{cc}
\hline AngkaIndeks & Tingkat Kepuasan \\
\hline $0.00 \leq \mathrm{x} \leq 24.99$ & Sangat Tidak Loyal \\
$25.00<\mathrm{x} \leq 49.99$ & Tidak Loyal \\
$50.00<\mathrm{x} \leq 74.99$ & Loyal \\
$75.00<\mathrm{x} \leq 100.00$ & Sangat Loyal \\
\hline
\end{tabular}

Sumber: (Rangkuti, 2005)

Kerangka pemikiran penelitian merupakan penjelasan sementara terhadap rumusan masalah yang telah dikemukakan sebelumnya sehingga menghasilkan kesimpulan yang berupa hipotesis penelitian. Kerangka pemikiran menggambarkan hubungan antara variabel bauran pemasaran, kepuasan pelanggan dan loyalitas pelanggan dan berada dalam kategori pengujian teori.

Hasil evaluasi dari variabel bauran pemasaran yang berpengaruh signifikan terhadap variabel kepuasan dan loyalitas pelanggan yang diperoleh dari hasil analisis Structural Equation Model Partial Least Square (SEM PLS) dan hasil customer satisfication index (CSI) berupa implikasi manajerial. Hal ini diharapkan dapat menjadi rekomendasi bagi pihak perusahaan untuk mengevaluasi kinerja bauran pemasaran, sehingga diketahui mana 
variabel dan indikator dari bauran pemasaran yang harus ditingkatkan dan yang harus dipertahankan. Kerangka pemikiran penelitian dapat dilihat pada Gambar 3.

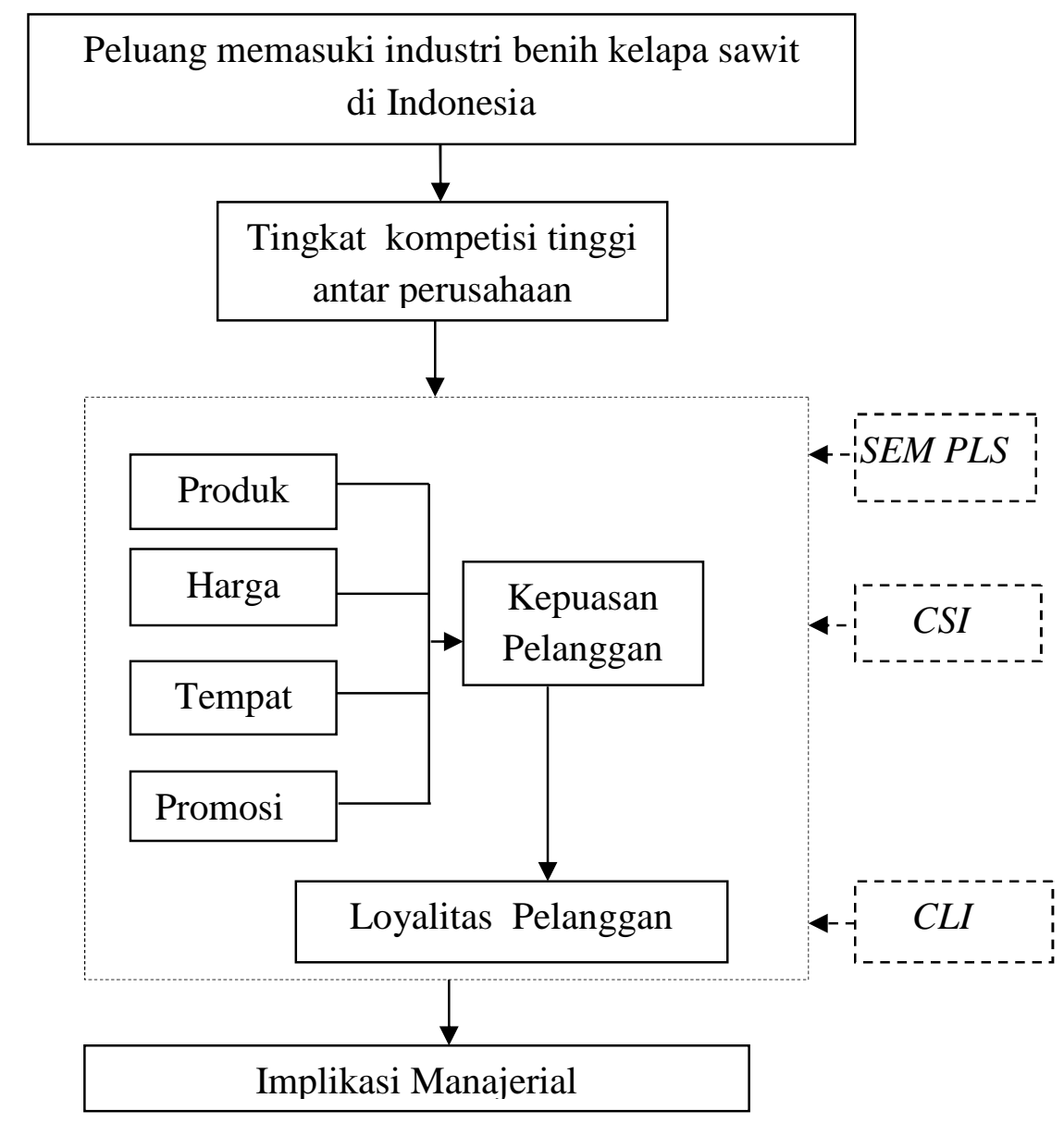

Keterangan :

Gambar 3 Kerangka pemikiran penelitian

Berdasarkan kerangka pemikiran di atas dapat dirumuskan hipotesis penelitian sebagai berikut ini:

$\mathrm{H}_{1}$ : Produk secara langsung berpengaruh positif dan signifikan terhadap kepuasan pelanggan.

$\mathrm{H}_{2}$ : Harga secara langsung berpengaruh positif dan signifikan terhadap kepuasan pelanggan.

$\mathrm{H}_{3}$ :Tempat secara langsung berpengaruh positif dan signifikan terhadap kepuasan pelanggan.

$\mathrm{H}_{4}$ :Promosi secara langsung berpengaruh positif dan signifikan terhadap kepuasan pelanggan.

$\mathrm{H}_{5}$ :Kepuasan secara langsung berpengaruh positif dan signifikan terhadap loyalitas pelanggan. 


\section{HASIL DAN PEMBAHASAN}

Evaluasi Model Pengukuran. Evaluasi output model SEM PLS yang terdiri atas dua tahapan, yakni evaluasi model pengukuran (outer model) dan evaluasi model struktural (inner model). Tujuan dilakukan evaluasi model pengukuran (outer model) yakni agar model yang dibangun memiliki indikator yang dapat menjelaskan konstruk dan semua indikator secara individu konsisten dengan pengukurannya. Evaluasi model pengukuran (outer model) terdiri atas evaluasi validitas (validitas konvergen dan validitas diskriminan) dan evaluasi reliabilitas melalui beberapa pengujian berdasarkan parameter yaitu validitas konvergen (convergent validity) menggunakan parameter loading factor dan Average Variance Extracted (AVE), validitas diskriminan (discriminant validity) melalui validitas diskriminan kriteria cross loading dan validitas diskriminan kriteria fornell-larcker. Sedangkan evaluasi reliabilitas melalui parameter composite reliability $(C R)$.

Berdasarkan hasil evaluasi model pengukuran pada model awal, diperoleh beberapa variabel indikator yang dinilai tidak dapat merefleksikan konstruknya karena memiliki nilai loading factor $(\lambda)$ kurang dari 0.5. yakni variabel indikator X11 (daya kecambah), variabel indikator X15 (ketahanan terhadap hama dan penyakit) dan variabel indikator X16 (kualitas kemasan). Perbaikan model dapat dilakukan dengan menghilangkan atau mengeluarkan variabel indikator yang tidak memenuhi kriteria kelayakan tersebut. Tahapan selanjutnya adalah melakukan proses ulang dengan tanpa melibatkan variabelvariabel indikator yang sudah dihilangkan atau dikeluarkan untuk memperoleh model yang terbaik. Hasil evaluasi model pengukuran dapat dilihat pada Gambar 4.

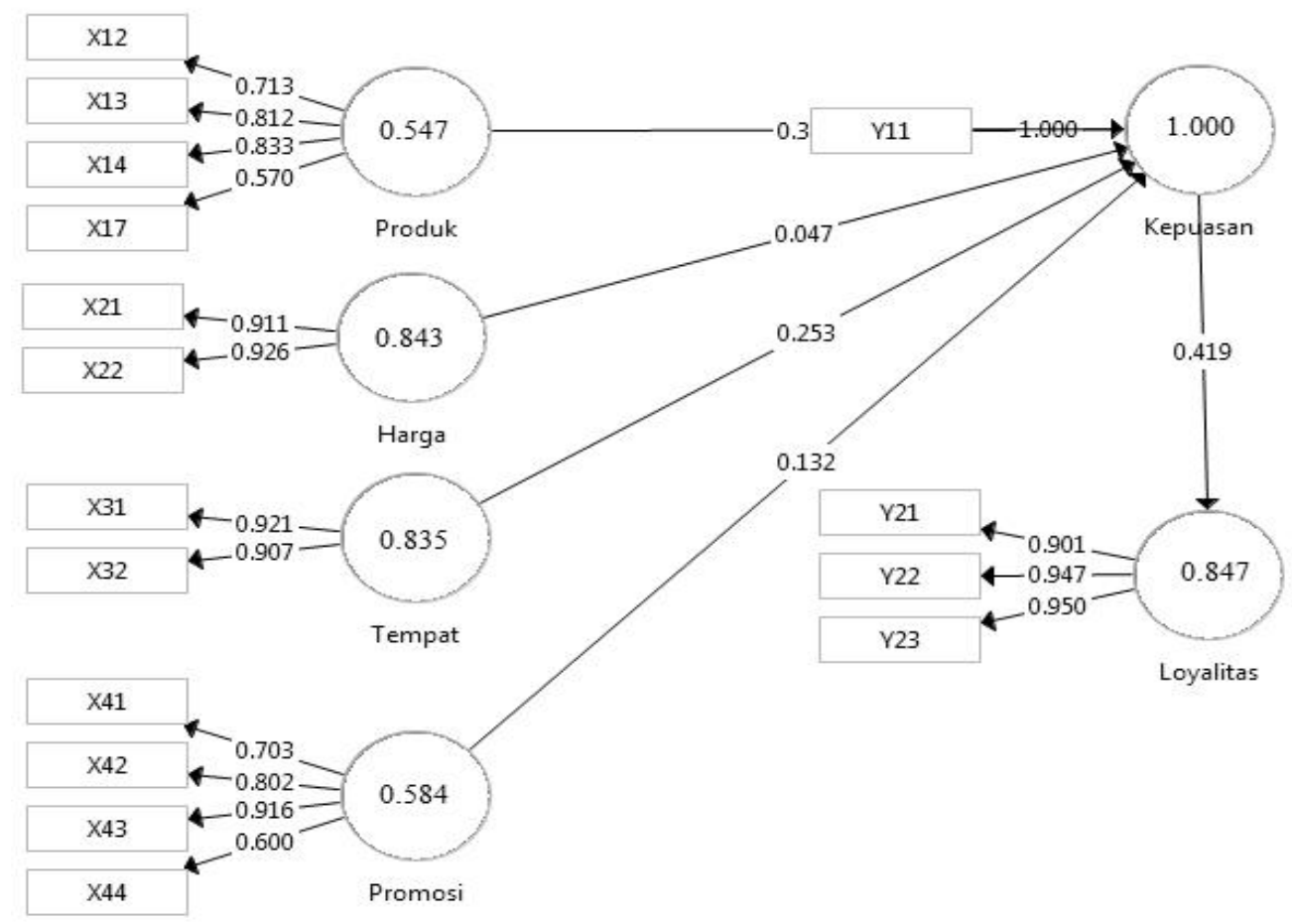

Gambar 4. Tampilan hasil SEM PLS algorithm model pengukuran

Tabel 4 menunjukkan bahwa hasil uji validitas diskriminan kriteria cross loading telah memenuhi kriteria. Masing-masing indikator yang ada pada variabel laten memiliki 
perbedaan dengan indikator di variabel lain yang ditunjukkan dengan skor loading-nya yang lebih tinggi di konstruknya sendiri bila dibandingkan dengan konstruk yang lain.

Tabel 4 Analisis validitas diskriminan kriteria cross loading

\begin{tabular}{clllccc}
\hline Indikator & Produk & Harga & Tempat & Promosi & Kepuasan & Loyalitas \\
\hline X12 & 0.71 & 0.39 & 0.18 & 0.13 & 0.40 & 0.13 \\
X13 & 0.81 & 0.39 & 0.28 & 0.32 & 0.36 & 0.12 \\
X14 & 0.83 & 0.45 & 0.53 & 0.43 & 0.44 & 0.12 \\
X17 & 0.57 & 0.28 & 0.13 & 0.40 & 0.42 & 0.49 \\
X21 & 0.48 & 0.91 & 0.36 & 0.33 & 0.35 & 0.63 \\
X22 & 0.47 & 0.93 & 0.44 & 0.39 & 0.39 & 0.63 \\
X31 & 0.24 & 0.42 & 0.92 & 0.14 & 0.41 & 0.22 \\
X32 & 0.47 & 0.38 & 0.91 & 0.02 & 0.38 & 0.15 \\
X41 & 0.09 & 0.30 & -0.12 & 0.70 & 0.19 & 0.43 \\
X42 & 0.45 & 0.29 & 0.16 & 0.80 & 0.23 & 0.23 \\
X43 & 0.45 & 0.38 & 0.11 & 0.80 & 0.39 & 0.34 \\
X44 & 0.29 & 0.16 & 0.08 & 0.60 & 0.10 & 0.18 \\
Y11 & 0.56 & 0.40 & 0.43 & 0.34 & 1.00 & 0.42 \\
Y21 & 0.10 & 0.57 & 0.06 & 0.36 & 0.31 & 0.90 \\
Y22 & 0.37 & 0.66 & 0.10 & 0.40 & 0.38 & 0.95 \\
Y23 & 0.32 & 0.67 & 0.35 & 0.33 & 0.46 & 0.95 \\
\hline
\end{tabular}

Setelah kriteria analisis validitas diskriminan kriteria cross loading terpenuhi, maka selanjutnya melakukan evaluasi validitas diskriminan kriteria fornell-larcker. Bila pada cross loading melihat perbandingan inter-korelasi antar konstruk, yakni variabel laten terhadap variabel indikatornya (manifest), evaluasi validitas diskriminan kriteria fornelllarcker justru ingin melihat perbandingan inter-korelasi antar variabel latennya. Tabel 5 menunjukkan bahwa variabel laten dengan skor loading-nya yang lebih tinggi di konstruknya sendiri bila dibandingkan dengan variabel lain. Maka dapat disimpulkan bahwa data yang digunakan telah memenuhi uji validitas diskriminan.

Tabel 5 Analisis Validitas Diskriminan Kriteria Fornell-Larcker

\begin{tabular}{cllllll}
\hline Peubah Laten & Harga & Kepuasan & Loyalitas & Produk & Promosi & Tempat \\
\hline Harga & 0.92 & & & & & \\
Kepuasan & 0.40 & 1.00 & & & & \\
Loyalitas & 0.68 & 0.42 & 0.93 & & & \\
Produk & 0.52 & 0.56 & 0.30 & 0.74 & & \\
Promosi & 0.39 & 0.34 & 0.39 & 0.44 & 0.76 & \\
Tempat & 0.44 & 0.43 & 0.20 & 0.39 & 0.09 & 0.91 \\
\hline
\end{tabular}

Selain itu, kriteria hasil evaluasi validitas konvergen dari setiap variabel indikator telah dipenuhi. Hal ini dibuktikan dengan semua variabel indikator memiliki nilai loading factor $(\lambda) \geq 0.50$, nilai Average Variance Extracted (AVE) $\geq 0.5$. Hasil evaluasi reliabilitas dengan kriteria nilai Composite reliability (CR) $\geq 0.7$ juga telah dipenuhi. Hal ini sesuai dengan kriteria evaluasi model pengukuran berdasarkan Latan dan Gozali (2015) dan Hair et al (2012). Ringkasan hasil evaluasi model pengukuran (outer model) berupa loading factor, average variance extracted, dan composite reliability dapat dilihat pada pada Tabel 6. Hasil evaluasi model pengukuran (outer model) menunjukkan bahwa model penelitian 
valid dan reliable sehingga dapat dilakukan uji selanjutnya yakni evaluasi model struktural (model inner).

Tabel 6 . Loading Factor, Average Variance Extracted, dan Composite Reliability

\begin{tabular}{|c|c|c|c|c|}
\hline $\begin{array}{l}\text { Variabel } \\
\text { Laten }\end{array}$ & Variabel Manifest & $\begin{array}{c}\lambda \\
(>0.5)\end{array}$ & $\begin{array}{l}\text { AVE } \\
(>0.5)\end{array}$ & $\begin{array}{r}\mathrm{CR} \\
(>0.7)\end{array}$ \\
\hline \multirow{4}{*}{ Produk } & Homogenitas ukuran benih (X12) & 0.713 & \multirow{4}{*}{0.547} & \multirow{4}{*}{0.826} \\
\hline & Rerata potensi produksi TBS (X13) & 0.812 & & \\
\hline & Rerata potensi ekstraksi CPO (X14) & 0.833 & & \\
\hline & Layanan purna Jual (X17) & 0.570 & & \\
\hline \multirow[t]{2}{*}{ Harga } & Harga benih sesuai mutu (X21) & 0.911 & \multirow[b]{2}{*}{0.843} & \multirow[b]{2}{*}{0.915} \\
\hline & $\begin{array}{l}\text { Harga benih sesuai yang diinginkan } \\
\text { (X22) }\end{array}$ & 0.926 & & \\
\hline \multirow[t]{2}{*}{ Tempat } & $\begin{array}{l}\text { Kemudahan akses dalam pembelian } \\
\text { benih (X31) }\end{array}$ & 0.921 & \multirow[t]{2}{*}{0.835} & \multirow[t]{2}{*}{0.910} \\
\hline & Ketepatan waktu pengiriman (X32) & 0.907 & & \\
\hline \multirow{4}{*}{ Promosi } & Bekerjasama dengan pihak lain (X41) & 0.703 & \multirow{4}{*}{0.584} & \multirow{4}{*}{0.846} \\
\hline & $\begin{array}{l}\text { Iklan di media online atau media cetak } \\
\text { (X42) }\end{array}$ & 0.802 & & \\
\hline & Pemberian bonus pembelian (X43) & 0.916 & & \\
\hline & $\begin{array}{l}\text { Penjualan perorangan (personal selling) } \\
\text { (X44) }\end{array}$ & 0.600 & & \\
\hline Kepuasan & Berdasarkan pengalaman pelanggan puas & & & \\
\hline Pelanggan & $\begin{array}{l}\text { terhadap kualitas benih kelapa sawit PT } \\
\text { Socfindo (Y11) }\end{array}$ & 1.000 & 1.000 & 1.000 \\
\hline \multirow{4}{*}{$\begin{array}{l}\text { Loyalitas } \\
\text { Pelanggan }\end{array}$} & Pelanggan akan tetap membeli benih & 0.901 & \multirow{4}{*}{0.870} & \multirow{4}{*}{0.953} \\
\hline & kelapa sawit PT Socfindo (Y21) & & & \\
\hline & $\begin{array}{l}\text { Pelanggan akan tetap membeli benih } \\
\text { kelapa sawit PT Socfindo meski ada } \\
\text { produsen benih kelapa sawit pesaing } \\
\text { (Y22) }\end{array}$ & 0.947 & & \\
\hline & $\begin{array}{l}\text { Pelanggan bersedia untuk } \\
\text { merekomendasikan benih kelapa sawit } \\
\text { PT Socfindo kepada pihak lain (Y23) }\end{array}$ & 0.950 & & \\
\hline
\end{tabular}

Evaluasi Model Struktural. Evaluasi model struktural (inner model) digunakan untuk melihat bagaimana hubungan antara konstruk laten dengan hasil estimasi koefisien parameter jalur dan tingkat signifikansinya. Hasil analisis mengenai sebaran R-square, menunjukkan bahwa variabilitas konstruk kepuasan pelanggan dapat dijelaskan secara moderat oleh variabilitas konstruk bauran pemasaran (produk, harga, tempat, promosi) yaitu sebesar 38 persen dan sisanya sebesar 62 persen, dijelaskan oleh variabel lain di luar model. Sedangkan variabilitas konstruk loyalitas pelanggan hanya mampu dijelaskan secara lemah oleh variabilitas konstruk bauran pemasaran dan kepuasan pelanggan sebesar 18 persen, dan sisanya 82 persen dijelaskan oleh variabel lain di luar model. Namun Rsquare bukanlah parameter absolute dalam mengukur ketepatan model prediksi karena dasar hubungan teoritis adalah parameter yang paling utama untuk menjelaskan hubungan kausalitas tersebut (Abdillah dan Jogiyanto 2015).

Selanjutnya nilai Q-square yang diperoleh yakni 0.49. Nilai Q-square >0, hal ini menunjukkan bahwa variabel laten eksogen sebagai variabel penjelas mampu 
memprediksi variabel laten endogennya. Selain itu, nilai goodness of fit yang dihasilkan sebesar 0.47 yakni lebih besar dari 0.26. Maka dapat disimpulkan bahwa goodness of fit model penelitian ini termasuk dalam kategori besar yang artinya kesesuaian model tergolong tinggi. Aturan evaluasi model struktural SEM PLS dapat dilihat pada Tabel 7.

Tabel 7. Aturan evaluasi model struktural SEM PLS

\begin{tabular}{cl}
\hline Kriteria & \multicolumn{1}{c}{ Rule of thumb } \\
\hline $\mathrm{R}^{2}$ & $0.67:$ Substansial; 0.33: Moderate; 0.19: Lemah \\
$\mathrm{Q}^{2}$ & $\mathrm{Q}^{2}>0$ menunjukkan model mempunyai predictiverelevance dan \\
& jika $\mathrm{Q}^{2}<0$ menunjukkan bahwa model kurang memiliki \\
predictive relevance. \\
GoF & $0.02:$ kecil; 0.13: Medium; dan $0.26:$ Besar \\
\hline
\end{tabular}

Sumber : (Latan dan Gozali, 2015)

Tahap terakhir pada evaluasi model struktural (inner model) adalah uji signifikansi hubungan-hubungan antar konstruk yang dipergunakan sebagai dasar dalam melakukan uji hipotesis. Uji ini dapat dilihat dari nilai signifikansi statistiknya diatas nilai T-tabel dengan $(\alpha 0.05$; T-tabel 1.96).

Hasil uji signifikansi menunjukkan bahwa variabel produk berpengaruh positif dan signifikan terhadap variabel kepuasan dengan hasil uji $\mathrm{T} 2.44>1.96$. Ekspektasi pelanggan benih kelapa sawit PT Socfindo lebih menekankan kepada mutu benih. Hasil ini sesuai dengan penelitian Liwang (2011) yang menyatakan bahwa mutu benih dianggap sangat penting karena berkorelasi dengan produktivitas tanaman kelapa sawit nantinya. Wajib bagi perusahaan untuk mempertahankan kualitas produk karena pelanggan lebih sadar akan kualitas daripada harga (Rajput et al., 2012).

Pada penelitian ini, variabel produk memiliki empat variabel indikator yang dapat merefleksikan konstruknya yakni homogenitas ukuran benih, rerata potensi produksi TBS, rerata potensi ekstraksi CPO, dan layanan purna jual. Hal yang berkenaan mengenai mutu benih yakni homogenitas ukuran benih karena hal ini berpengaruh terhadap homogenitas perkembangan bibit hingga menjadi tanaman kelapa sawit, selanjutnya mengenai rerata potensi produksi TBS yang mencapai 29-34 ton/ha dan rerata potensi ekstraksi CPO yang mencapai 26-28 persen. Hal ini menjadi titik tolak apakah benih yang dihasilkan berkualitas atau tidak. Hasil rerata produksi yang tinggi merupakan kepuasan pelanggan karena dapat menikmati keuntungan dari kualitas benih kelapa sawit PT Socfindo. Indikator terakhir dari variabel produk yakni layanan purna jual. Indikator ini tidak kalah penting dari perhatian pelanggan dalam membeli benih kelapa sawit di PT Socfindo. Hasil penelitian Kisu (2015) mengenai benih menyatakan bahwa layanan purna jual merupakan strategi yang paling sukses untuk bersaing di pasar yang kompetitif.

Selanjutnya untuk uji siginifikansi variabel kepuasan berpengaruh positif dan signifikan terhadap loyalitas pelanggan dengan hasil uji T $2.64>1.96$. Hasil penelitian ini sesuai dengan penelitian Nuseir dan Madanat, (2015) yang menyatakan bahwa variabel kepuasan memiliki pengaruh signifikan terhadap loyalitas pelanggan. Variabel kepuasan pelanggan merupakan variabel yang memediasi hubungan antara bauran pemasaran dan loyalitas.

Sementara untuk variabel harga, memiliki hasil uji T $0.23<1.96$. Artinya variabel tersebut tidak berpengaruh siginfikan terhadap variabel kepuasan. Harga benih kelapa sawit PT Socfindo bila dibandingkan dengan beberapa perusahaan pesaing, relatif mahal. 
Namun pelanggan benih kelapa sawit PT Socfindo beranggapan bahwa harga adalah cerminan dari kualitas. Dengan harga yang lebih mahal, maka mutu benih kelapa sawit PT Socfindo lebih baik dari benih kelapa sawit lainnya. Sehingga variabel harga tidak berpengaruh terhadap kepuasan pelanggan. Namun, hasil penelitian Kisu, (2015) menyatakan bahwa dengan bertambahnya kompetitor dalam pasar benih, strategi harga tinggi perlu mempertimbangkan biaya produksi dan pesaing sebelum memutuskan harga jual benih perusahaan. Hal ini akan memungkinkan para pelanggan untuk membeli benih dari perusahaan dari perusahaan lain sebagai perbandingan.

Variabel distribusi memiliki hasil uji T $1.18<1.96$. Hal ini berarti variabel distribusi tidak berpengaruh siginfikan terhadap variabel kepuasan. Akses pembelian yang mudah dan ketersediaan benih kelapa sawit yang selalu tepat pada waktunya. Sehingga pelanggan beranggapan bahwa variabel distribusi tidak berpengaruh terhadap kepuasan pelanggan dalam membeli benih kelapa sawit PT Socfindo.

Selain itu, variabel promosi memiliki hasil uji T $0.75<1.96$. Artinya variabel promosi tidak berpengaruh siginifikan terhadap variabel kepuasan. Pelanggan beranggapan bahwa PT Socfindo merupakan produsen lama pada pasar benih kelapa sawit di Indonesia sehingga variabel promosi tidak lagi mengindikasikan kepuasan pelanggan.

Sehingga pada penelitian ini, variabel bauran pemasaran yang berpengaruh signifikan terhadap variabel kepuasan pelanggan hanya variabel produk. Variabel produk memiliki pengaruh terbesar dalam membentuk kepuasan yang selanjutnya akan membentuk loyalitas pelanggan. Indikator-indikator pada variabel produk mampu berpengaruh lebih besar dalam menstimuli pelanggan untuk secara signifikan mengukur kepuasan. Secara lebih lengkap, nilai-nilai hasil uji signifikansi tersebut disajikan pada Tabel 8.

Tabel 8. Hasil uji hipotesis

\begin{tabular}{lcc}
\hline Hipotesis & $\begin{array}{c}\text { Original } \\
\text { Sample }\end{array}$ & $T$ \\
& 0.38 & Statistic \\
\hline Produk $\rightarrow$ Kepuasan & 0.05 & $2.44^{*}$ \\
Harga $\rightarrow$ Kepuasan & 0.25 & 0.23 \\
Tempat $\rightarrow$ Kepuasan & 0.13 & 1.18 \\
Promosi $\rightarrow$ Kepuasan & 0.42 & 0.75 \\
Kepuasan $\rightarrow$ Loyalitas & & $2.64^{*}$ \\
\hline
\end{tabular}

Tingkat Kepuasan Pelanggan. Tingkat kepuasan pelanggan benih kelapa sawit PT Socfindo dapat diketahui dengan mengukur customer satisfication index (CSI). Indikator yang memiliki indeks kepuasan tertinggi adalah rerata potensi produksi TBS yakni sebesar 11.468. Hal ini menunjukkan kinerja PT Socfindo dalam menghasilkan TBS dengan rerata produksi 29-34 ton/Ha sesuai dengan ekspektasi pelanggan. Produksi tandan buah segar (TBS) yang tinggi merupakan indikasi bahwa benih kelapa sawit PT Socfindo berkualitas. Pelanggan merasa sangat puas, karena dengan rerata produksi TBS yang tinggi tentunya akan meningkatkan laba dan profitabilitas perusahaan.

Sedangkan indikator yang memiliki nilai indeks kepuasan terendah adalah indikator harga benih sesuai dengan yang diinginkan. Nilai indeks kepuasan indikator tersebut sebesar 1.269. PT Socfindo menerapkan strategi harga tinggi untuk produk benih kelapa sawit dengan alasan harga yang tinggi mengisyaratkan bahwa produk memiliki kualitas yang sangat tinggi. Namun dengan kondisi adanya peningkatan jumlah produsen pada 
pasar benih kelapa sawit, pelanggan akan memiliki banyak pilihan produsen benih kelapa sawit dan akan melakukan banyak pertimbangan dalam menentukan produsen benih kelapa sawit mana yang akan dijadikan supplier dalam penyediaan benih kelapa sawit di perusahaannya. Penerapan harga tinggi dari pihak produsen benih kelapa sawit akan membuat pelanggan untuk berpikir ulang dan memungkinkan berpindah ke produsen benih kelapa sawit yang lain.

Nilai customer satisfication index (CSI) secara keseluruhan adalah sebesar 77.185. Sesuai dengan kriteria nilai kepuasan berada pada level "sangat puas". Hal ini mengindikasikan bahwa sebagian besar pelanggan PT Socfindo merasa sangat puas terhadap kinerja yang dilakukan oleh pihak perusahaan. Hasil analisis customer satisfication index (CSI) dapat dilihat pada Tabel 9.

Tabel 9. Indeks kepuasan pelanggan benih kelapa sawit PT Socfindo

\begin{tabular}{lcccccc}
\hline Variabel Manifest & $\begin{array}{l}\text { Loading } \\
\text { Factor }\end{array}$ & $\begin{array}{c}\text { Koef } \\
\text { Konstruk }\end{array}$ & $\begin{array}{c}\text { Besar } \\
\text { Pengaruh }\end{array}$ & Bobot & $\begin{array}{c}\text { CSI } \\
\%\end{array}$ & $\begin{array}{c}\text { CSI per } \\
\text { Indikator }\end{array}$ \\
\hline $\begin{array}{l}\text { Produk } \\
\text { Homogenitas ukuran }\end{array}$ & 0.713 & 0.379 & 0.270 & 0.131 & 73.33 & 9.632 \\
$\begin{array}{l}\text { benih } \\
\text { Rerata potensi produksi }\end{array}$ & 0.812 & 0.379 & 0.308 & 0.150 & 76.67 & $\mathbf{1 1 . 4 6 8}$ \\
$\begin{array}{l}\text { TBS } \\
\text { Rerata potensi ekstraksi }\end{array}$ & 0.833 & 0.379 & 0.316 & 0.153 & 66.67 & 10.230 \\
$\begin{array}{l}\text { CPO } \\
\text { Layanan purna Jual }\end{array}$ & 0.570 & 0.379 & 0.216 & 0.105 & 60.00 & 6.300 \\
$\begin{array}{l}\text { Harga } \\
\text { Harga benih sesuai mutu }\end{array}$ & 0.911 & 0.047 & 0.043 & 0.021 & 73.30 & 1.526 \\
$\begin{array}{l}\text { Harga benih sesuai yang } \\
\text { diinginkan }\end{array}$ & 0.926 & 0.047 & 0.044 & 0.021 & 60.00 & $\mathbf{1 . 2 6 9}$ \\
$\begin{array}{l}\text { Tempat } \\
\text { Kemudahan akses dalam } \\
\text { pembelian benih }\end{array}$ & 0.921 & 0.253 & 0.233 & 0.113 & 100.00 & 11.326 \\
$\begin{array}{l}\text { Ketepatan waktu } \\
\text { pengiriman }\end{array}$ & 0.907 & 0.253 & 0.229 & 0,112 & 100.0 & 11.154 \\
$\begin{array}{l}\text { Promosi } \\
\text { Bekerjasama dengan } \\
\text { pihak lain }\end{array}$ & 0.703 & 0.132 & 0.093 & 0,045 & 73.30 & 3.306 \\
$\begin{array}{l}\text { Iklan di media online } \\
\text { atau media cetak }\end{array}$ & 0.802 & 0.132 & 0.106 & 0.051 & 73.30 & 3.772 \\
$\begin{array}{l}\text { Pemberian bonus } \\
\text { pembelian }\end{array}$ & 0.916 & 0.132 & 0.121 & 0.059 & 76.67 & 4.506 \\
$\begin{array}{l}\text { Penjualan perorangan } \\
\text { personal selling) }\end{array}$ & 0.600 & 0.132 & 0.079 & 0.038 & 70.00 & 2.695 \\
$\begin{array}{l}\text { Total } \\
\text { CSI }\end{array}$ & & & 2.057 & & & 77.185 \\
\hline
\end{tabular}

Tingkat Loyalitas Pelanggan. Berdasarkan hasil analisis Customer Loyalty Index (CLI), indikator pelanggan akan tetap membeli benih kelapa sawit PT Socfindo memiliki nilai indeks loyalitas per indikator paling tinggi sebesar 22.540 dan indikator yang memiliki nilai indeks loyalitas per indikator terendah yakni indikator pelanggan akan tetap membeli benih kelapa sawit PT Socfindo meski ada produsen benih kelapa sawit pesaing, dengan nilai indeks sebesar 18.025. Hal ini mengindikasikan bahwa dengan adanya new comers 
pada pasar benih kelapa sawit di Indonesia mengakibatkan pelanggan benih kelapa sawit PT Socfindo memiliki kemungkinan untuk melakukan pembagian jumlah benih kelapa sawit yang akan dibeli kepada produsen lain ataupun beralih ke produsen benih kelapa sawit yang lain meskipun sudah merasa sangat puas dengan benih kelapa sawit PT Socfindo.

Hasil perhitungan CLI secara keseluruhan yakni:

$$
\mathrm{CLI} \quad=\frac{62.034+77.185}{2}=69.609
$$

Sesuai dengan kriteria nilai loyalitas, CLI sebesar 69.609 berada pada level "loyal". Hal ini sesuai dengan hasil penelitian Liwang et al., (2012) bahwa tingkat kepuasan konsumen tidak menjamin sepenuhnya bahwa konsumen akan melakukan pembelian untuk produk dengan merk yang sama di masa yang akan datang. Tabel 10 menunjukkan hasil perhitungan Customer Loyalty Index (CLI) pada penelitian ini.

Tabel 10. Indeks loyalitas pelanggan benih kelapa sawit PT Socfindo

\begin{tabular}{lccccc}
\hline \multicolumn{1}{c}{ Variabel Manifest } & $\begin{array}{l}\text { Loading } \\
\text { Factor }\end{array}$ & $\begin{array}{c}\text { Besar } \\
\text { Pengaruh }\end{array}$ & Bobot & $\begin{array}{c}\text { CLI } \\
\%\end{array}$ & $\begin{array}{c}\text { CLI per } \\
\text { Indikator }\end{array}$ \\
\hline $\begin{array}{l}\text { Pelanggan akan tetap membeli benih } \\
\text { kelapa sawit PT Socfindo }\end{array}$ & 0.901 & 0.901 & 0.322 & 70.000 & $\mathbf{2 2 . 5 4 0}$ \\
$\begin{array}{l}\text { Pelanggan akan tetap membeli benih } \\
\text { kelapa sawit PT Socfindo meski ada } \\
\text { produsen benih kelapa sawit pesaing }\end{array}$ & 0.947 & 0.947 & 0.338 & 53.333 & $\mathbf{1 8 . 0 2 5}$ \\
$\begin{array}{l}\text { Pelanggan bersedia untuk } \\
\text { merekomendasikan benih kelapa }\end{array}$ & 0.950 & 0.950 & 0.339 & 63.333 & 21.469 \\
$\begin{array}{l}\text { sawit PT Socfindo kepada pihak lain } \\
\text { Total }\end{array}$ & & & & & \\
CLI & & 2.798 & & & 62.034 \\
\hline
\end{tabular}

Implikasi Manajerial. Evaluasi kinerja indikator bauran pemasaran benih kelapa sawit PT Socfindo dilakukan dengan mengevaluasi nilai indeks kepuasan variabel indikator pada analisis customer satisfication index (CSI). Indikator yang dievaluasi berasal dari variabel bauran pemasaran yang berpengaruh signifikan terhadap kepuasan dan loyalitas pelanggan benih kelapa sawit PT Socfindo. Berdasarkan hasil analisis Structural Equation Model Partial Least Square (SEM PLS), variabel produk merupakan variabel yang berpengaruh signifikan terhadap kepuasan dan loyalitas pelanggan benih kelapa sawit PT Socfindo.

Indikator variabel produk yang memiliki nilai bobot lebih besar dari 0.05 , artinya indikator tersebut memiliki pengaruh yang besar terhadap peningkatan kepuasan dan loyalitas pelanggan benih kelapa sawit PT Socfindo namun kinerja aktual perusahaan terhadap indikator tersebut rendah sehingga perlu diperbaiki atau ditingkatkan.

Indikator pertama yang harus diperhatikan oleh pihak perusahaan adalah indikator homogenitas ukuran benih. Pihak perusahaan PT Socfindo perlu meningkatkan kinerja dari indikator homogenitas benih kelapa sawit sehingga dapat meningkatkan kepuasan dan loyalitas pelanggan. Benih yang tidak homogen pertumbuhannya juga cenderung tidak homogen, tentunya hal ini nantinya akan berdampak pada pertumbuhan benih hingga berkembang menjadi bibit dan tanaman kelapa sawit. 
Indikator rerata potensi produksi TBS dan indikator rerata potensi ekstraksi CPO perlu mendapat perhatian dari perusahaan PT Socfindo karena kinerjanya dianggap masih belum maksimal. Tujuan pelanggan mengharapkan benih yang berkualitas yakni benih kelapa sawit yang nantinya akan menjadi tanaman kelapa sawit yang memiliki rerata produksi TBS dan rerata ekstraksi CPO yang tinggi. Hal ini nantinya akan berpengaruh terhadap kualitas produk turunan dari CPO.

Indikator selanjutnya yakni indikator layanan purna jual. Indikator layanan purna jual merupakan indikator yang sangat perlu mendapat perhatian dari perusahaan PT Socfindo karena memiliki nilai indeks kepuasan yang paling rendah diantara indikator yang lain. Ini artinya kinerja dari indikator layanan purna jual sangat jauh dari yang diharapkan oleh pelanggan.

\section{PENUTUP}

Simpulan. Variabel bauran pemasaran yang berpengaruh signifikan terhadap kepuasan dan loyalitas pelanggan benih kelapa sawit PT Socfindo yakni variable produk. Tingkat kepuasan pelanggan benih kelapa sawit PT Socfindo berada pada kategori 'sangat puas'. Sementara tingkat loyalitas pelanggan benih kelapa sawit PT Socfindo berada pada tingkat 'loyal'.

Saran. Implikasi manajerial yang direkomendasikan kepada pihak manajemen PT Socfindo untuk meningkatkan kepuasan dan loyalitas pelanggan benih kelapa sawit PT Socfindo yaitu perbaikan terhadap kinerja indikator homogenitas ukuran benih, rerata potensi produksi TBS, rerata potensi ekstraksi CPO dan layanan purna jual.

\section{DAFTAR RUJUKAN}

Almuala, A., dan M. Alqurneh. (2012) "Assessing the Relationship between Marketing Mix and Loyalty through Tourists Satisfaction in Jordan Curative Tourism". American Academic \& Scholarly Research Journal. 4 (2).

[BPS] Badan Pusat Statistik. (2014) "Luas Areal dan Produksi Kelapa Sawit Indonesia. Jakarta (ID)". (Retrifed from : http://www. bps.go.id/15-01- 2016).

Chinomona R., dan D. Dubihlela. (2014) "Does Customer Satisfaction Lead to Customer Trust, Loyalty and Repurchase Intention of Local Store Brands? The Case of Gauteng Province of South Africa". Mediterranean Journal of Social Sciences. 5 (9).

[DITJETBUN)] Direktorat Jenderal Perkebunan Kementerian Pertanian RI. 2016. Alamat Produsen Benih Kelapa Sawit Tahun 2016. Jakarta (ID). (Retrifed from: http://www. deptan.go.id/ 16-01-2016).

Dutka, Alan. (2008) AMA Handbook for customer satisfication. NTC Business book. Lincolnwood, IIlinois.

[GAPKI] Gabungan Pengusaha Kelapa Sawit Indonesia. (2014) Industri Minyak Sawit Indonesia Menuju 100 Tahun NKRI Membangun Kemandirian Ekonomi, Energi dan Pangan Secara Berkelanjutan. Bogor (ID): GAPKI.

Hair, J.F., Ringle, C.M., Sarstedt, M., dan Mena, J.A. (2012) An Assessment of The Use of Partial Least Squares Structural Equation Modelling in Marketing Research. Journal of Academy of Marketing Science. 40(1), 414-433. 
Kanagal, Nagashimha. (2009) Role of relationship marketing in competitive marketing strategy. Journal of Management and Marketing Research. 2(5), 1-17.

Kisu, Japneth. (2015) "Effect Of Marketing Strategies On The Performance Of Seed Companies In Kenya", Tesis. Nairobi (KI): University of Nairobi.

Koes, Asrul. (2013) "Analisis Sikap, Kepuasan dan Loyalitas Petani Terhadap Penggunaan Benih Unggul Jagung Komposit Di Sulawesi Selatan”, Tesis. Bogor (ID): Institut Pertanian Bogor.

Kotler, P., dan Keller, K.L. (2009) Manajemen Pemasaran. Jakarta (ID): PT Indeks. Terjemahan dari Marketing Management.

Kurniawan, Heri. (2011) "Partial Least Square (PLS) Sebagai Metode Alternatif SEM Berbasis Varians (LISREL) dalam Eksplorasi Data Survey dan Data Mining”. Jurnal Telematika. 7(1).

Latan, H., dan Ghozali, I. (2015) Partial Least Square Konsep, Teknik dan Aplikasi Menggunakan Program SmartPLS 3.0. Semarang (ID): Badan Penerbit Universitas Diponegoro.

Levens M. (2010) Marketing: Defined, Explained, Applied, International Edition. New Jersey (NJ): Pearson Education Limited.

Li M., dan Green. R. (2012) A mediating influence on customer loyalty: The role of perceived value. Journal of Management and Marketing Research.

Liwang, T., Daryanto, A., Gumbira, E., dan Nuryartono, N. (2011) "Analisis Perilaku Konsumen Benih Kelapa Sawit di Indonesia”. Jurnal Sosial. 12 (1),114-127. (2012) "Analisa Dinamika Perkembangan Industri Benih Kelapa Sawit di Indonesia". Jurnal Ekonomi dan Sosial. 1(2), 115-125.

Mosahab R., Mahamad .O., dan Ramayah. T. (2010) "Service Quality, Customer Satisfaction and Loyalty: A Test of Mediation". International Business Research. 3(4).

Nuseir, M.T., dan Madanat, H. (2015) “4Ps: A Strategy to Secure Customers' Loyalty via Customer Satisfaction". International Journal of Marketing Studies. 7(4).

Raab ,G., Ajami R.A., Gargeya, V.B., dan Goddard GJ. 2008. Customer Relationship Management: A Global Perspective. England(GB): Gower Publishing Limited.

Rachmawati, Rina. (2011) "Peranan bauran pemasaran terhadap peningkatan penjualan". Jurnal Kompetensi Teknik. 2(2), 143-150.

Rajput, A.A., Kalhoro S.H., dan Wasif, R. (2012) "Impact of Product Price and Quality on Consumer Buying Behavior: Evidence from Pakistan”. Interdisciplinary Journal of Contemporary Research in Business. 4(4), 485-496.

Rangkuti, Freddy. (2005) Riset Pemasaran. Jakarta (ID): Gramedia Pustaka Utama.

Suthar, B.K., Lathangi, R., dan Pradhan, S. (2014) "Impacts of Marketing Mix and Customer Perception on Brand Loyalty". Global Journal of Finance and Management. 6(7), 619-636.

Suwarni dan Mayasari, S.W. (2011) "Pengaruh Kualitas Produk dan Harga terhadap Loyalitas melalui Kepuasan Konsumen”. Jurnal Ekonomi Bisnis. 16 (1).

Tjiptono, Fandy. (2008) Strategi Pemasaran. Yogyakarta (ID): Andi

Wills, B. (2009) The business case for environmental sustainability (Green). (Retrifed from: http://www.leanandgreensummit.com/ 20-04-2016).

Yamin, S dan Kurniawan, H. (2009) Structural Equation Model. Jakarta(ID): Salemba Infotek. 